\title{
What controls tadpole richness and guild composition in ponds in subtropical grasslands?
}

\author{
CAMILA BOTH, ${ }^{1,2 \star}$ SONIA ZANINI CECHIN, ${ }^{3}$ ADRIANO S. MELO ${ }^{4,5}$ AND \\ SANDRA M. HARTZ ${ }^{4}$ \\ ${ }^{1}$ Programa de Pós-Graduação em Ecologia, Universidade Federal do Rio Grande do Sul, ${ }^{2}$ Programa de \\ Pós-Graduação em Zoologia, Pontifícia Universidade Católica do Rio Grande do Sul, Porto Alegre, \\ Brazil, Av. Ipiranga, 6681 - Partenon - Porto Alegre/RS (Email: camilaboth@gmail.com), ${ }^{3}$ Dep. \\ Biologia, Universidade Federal de Santa Maria, Santa Maria, ${ }^{4}$ Dep. Ecologia, Universidade Federal do \\ Rio Grande do Sul, Porto Alegre, ${ }^{5}$ Dep. Ecologia, Instituto de Ciências Biológicas, Universidade Federal \\ de Goiás, Goiânia, Brazil
}

\begin{abstract}
The community structure of pond systems is affected by resource competition, predation and degree of permanence of water. Here we evaluated the effect of the permanence-predation gradient in ponds on species richness and guild composition of tadpoles. The study was carried out at Caçapava do Sul in southern Brazil. Tadpoles and invertebrate predators were sampled in 38 ponds of different sizes and degrees of permanence. The collections were carried out twice, in spring 2007 and summer 2008. We ordinated guild composition in ponds in a single dimension through a non-metric multidimensional scaling. The relationships between tadpole richness and guild composition with environmental descriptors were tested through multiple regression. The species were classified into six guilds. Species richness increased with the abundance of predators and the mean water depth in summer. The ordination of guild composition was explained by permanence and mean depth in summer. Our results indicated a clear guild replacement through a permanence-depth gradient, confirming permanence as an important environmental filter. Therefore, most rich ponds would not contain species from all groups, and even very small, shallow and ephemeral ponds are important, given that some species groups are exclusive to such habitats.
\end{abstract}

Key words: anuran larvae, community structure, environmental gradient, guild.

\section{INTRODUCTION}

Researchers examining community ecology seek to understand the patterns of spatial and temporal distribution of assemblages in a defined region, their richness predictors and the factors governing species interactions. The number of species and their abundances has been attributed to historical events and spatially structured stochastic processes, species interactions, and environmental gradients. Presently existing communities may exhibit a structure linked to their ancestors' interactions and environment (Hardy \& Senterre 2007), or they may exhibit no structure (Hubbell 2001). Space may itself be a factor important to communities, or may act through environmental spatially structured descriptors (Legendre \& Fortin 1989; Bocard et al. 1992; Ernst \& Rödel 2008). In turn, environmental gradients may act as ecological filters, governing the entry of species in a given system, and therefore determining species richness and

${ }^{\star}$ Corresponding author.

Accepted for publication July 2010. composition (Badgley \& Fox 2001; Werner et al. 2007; Devoto et al. 2009). Still, species interactions such as competition and predation may govern communities (Gotelli \& McCabe 2002; Krebs 2009).

The importance of each above-mentioned factor varies depending on the system studied, and some investigators have stated that community ecology has few or no general rules (Lawton 1999; Simberloff 2004). On the other hand, freshwater pond communities have been cited as good model systems, with a simple trophic cascade and structured by a small set of factors: competition, predation and period of permanence of water (Chase \& Leibold 2003; Simberloff 2004). In an extensive review of pond systems, Wellborn et al. (1996) pointed out that two main environmental filters drive the occupancy of ponds that differ in the degree of permanence: (i) desiccation, in ephemeral ponds; and (ii) fish predators, in permanent habitats. In their model, ponds with intermediate permanence shelter invertebrate predators, but not fish. The role of pond permanence gradients has been evaluated for many taxa, including macroinvertebrates, fishes and tadpoles. Macroinvertebrates and 
fishes increase in richness towards more permanent water-bodies (e.g. Kushlan 1976; Stenert \& Maltchik 2007). Larval amphibian richness shows a non-linear relationship with permanency, where lower species richness is found in the extreme portions of gradient (Wellborn et al. 1996; Werner et al. 2007).

Different species traits can be expected to predominate along different positions of environmental gradients. Good examples are found among larval amphibians. For instance, species that occur in temporary ponds tend to show rapid larval development (Skelly 1996), whereas those that coexist with predatory fish in permanent ponds tend to be unpalatable (Hero et al. 2001). Exposed to the same gradient, macroinvertebrates and fishes also change species composition, with predator species more frequent in permanent habitats (Kushlan 1976; Tarr et al. 2005; Vanschoenwinkel et al. 2009). Given the effects of the permanence-predation gradient on species traits, one should expect an extension of the effect on the distribution of entire guilds. This hypothesis, however, remains mostly untested using field data.

In this study, we tested the effect of a permanence gradient on the richness and guild composition of tadpoles in subtropical grassland ponds. For this purpose we determined tadpole guilds based on morphological and ecological traits. We also investigated the influence of additional potential variables on tadpole richness and guild composition, such as area, depth and heterogeneity of ponds (shore types and vegetation) (Eason \& Fauth 2001; Peltzer \& Lajmanovich 2004; Santos et al. 2007). Our expectation was that species richness would be well explained by the permanence-predation gradient, in accordance with previous studies. We hypothesized that the permanence-predation gradient will predict the entire guild composition.

\section{MATERIALS AND METHODS}

\section{Study area}

The study was carried out in the municipality of Caçapava do Sul, Rio Grande do Sul, Serra do Sudeste, southern Brazil (between $30^{\circ} 57^{\prime}$ and $31^{\circ} 03^{\prime} \mathrm{S}, 53^{\circ} 25^{\prime}$ and $53^{\circ} 89^{\prime} \mathrm{W}$ ). The vegetation is composed by grasslands with scattered trees or small forest patches. Large forest patches are present in hilly sites and valleys, and the major land use is cattle and sheep grazing. The climate is classified as Temperate Humid, with annual mean temperature of $16.8^{\circ} \mathrm{C}$ and annual precipitation of $1588 \mathrm{~mm}$ (Maluf 2000).

\section{Sampling}

We selected 38 ponds, separated from each other by distances of $0.3-80 \mathrm{~km}$. The ponds varied in terms of size and permanence. Tadpoles and potential predators were sampled in the austral spring (November 2007) and summer (January 2008). Each sampling event lasted 5-7 consecutive days. We opted to sample ponds in spring and summer because these are the periods of highest anuran richness at the breeding sites for austral communities (Both et al. 2008, 2009; Canavero et al. 2008). The ponds were swept all around, using a dip net $(0.4 \times 0.3 \mathrm{~m}, 0.5 \mathrm{~mm} \mathrm{mesh})$, to collect tadpoles and potential insect predators (Coleoptera, Hemiptera, Heteroptera and Odonata). Specimens collected were immediately fixed and stored in $10 \%$ formalin. The specimens are housed at the Herpetological Collection of the Universidade Federal de Santa Maria.

\section{Variables}

We measured the area and depth of each pond in each collection event. For depth, we took the mean of three to six measurements obtained in each pond, depending on its size. The ratio between the areas of the two sampling events (summer area/spring area) was used as a measure of pond permanence. We recorded hydrophyte richness (floating and emergent macrophytes) in the pond, and the structural vegetation types present on the periphery (grassy - low, grassy high, shrubs, trees).

\section{Statistical analyses}

\section{Delineation of guilds}

We based our guild delimitation on criteria suggested by Altig and Johnston (1989) and revised by McDiarmid and Altig (1999). We conducted a guild classification of the species studied, based on eight variables related to morphological and ecological features. The morphological variables were coded as categorical and included: eye position (dorsal/lateral), mouth position (terminal, subterminal, ventral) (see Faivovich 2002), spiracle position (lateral, terminal, ventral), height of dorsal and ventral tail fins (higher than the tail muscle at the body-tail juncture, or lower), and body height/width ratio (equal to or greater than one, or less than one).The ecological variables used were site of clutch deposition (directly in water, in trees or with foam nests), and presence/absence of schooling behaviour. The matrix of species by variables is presented in Table 1 . We obtained a similarity matrix using the Gower coefficient. This coefficient combine distinct type descriptors and process each one following to its own mathematical type, for example, binary, quantitative, qualitative (Legendre \& Legendre 1998). The partial similarity of each object is calculated, and the average similarity between descriptors determines the resultant similarity of two objects (Legendre \& Legendre 1998). We classified species into ecological guilds by Complete Linkage agglomerative clustering, because this method increases the contrast between groups (Legendre \& Legendre 1998). In naming the guilds, we attempted to match our results with previous classifications (Altig \& Johnston 1989; McDiarmid \& Altig 1999). The Gower coefficient was calculated in Multiv 2.4 (Pillar 2006) and the classification analysis was performed in STATISTICA 6.0 (Statsoft 2001). 
Table 1. Coding for eight ecomorphological features describing the tadpole guilds

\begin{tabular}{|c|c|c|c|c|c|c|c|c|}
\hline Species & $\begin{array}{c}\text { Eye } \\
\text { position }\end{array}$ & $\begin{array}{c}\text { Oral } \\
\text { position }\end{array}$ & $\begin{array}{l}\text { Dorsal } \\
\text { fin }\end{array}$ & $\begin{array}{l}\text { Ventral } \\
\text { fin }\end{array}$ & $\begin{array}{l}\text { Spiracle } \\
\text { position }\end{array}$ & $\begin{array}{l}\text { Body } \\
\text { ratio }\end{array}$ & $\begin{array}{l}\text { Schooling } \\
\text { behaviour }\end{array}$ & Clutch \\
\hline \multicolumn{9}{|l|}{ Cycloramphidae } \\
\hline Limnomedusa macroglossa & 1 & 3 & 0 & 0 & 1 & 2 & 0 & 1 \\
\hline \multicolumn{9}{|l|}{ Hylidae } \\
\hline Dendropsophus minutus & 0 & 2 & 1 & 1 & 1 & 1 & 0 & 1 \\
\hline Hypsiboas albopunctatus & 1 & 3 & 0 & 0 & 1 & 2 & 0 & 1 \\
\hline Hypsiboas pulchellus & 1 & 3 & 0 & 0 & 1 & 2 & 0 & 1 \\
\hline Phyllomedusa iheringii & 0 & 1 & 0 & 1 & 2 & 1 & 0 & 2 \\
\hline Pseudis minuta & 0 & 2 & 1 & 1 & 1 & 1 & 0 & 1 \\
\hline Scinax granulatus & 0 & 2 & 1 & 1 & 1 & 1 & 0 & 1 \\
\hline Scinax sp. & 0 & 2 & 1 & 1 & 1 & 1 & 0 & 1 \\
\hline Scinax fuscovarius & 0 & 2 & 1 & 1 & 1 & 1 & 0 & 1 \\
\hline \multicolumn{9}{|l|}{ Leiuperidae } \\
\hline Physalaemus gracilis & 1 & 3 & 0 & 0 & 1 & 2 & 0 & 3 \\
\hline Physalaemus riograndensis & 1 & 3 & 0 & 0 & 1 & 2 & 0 & 3 \\
\hline Physalaemus cuvieri & 1 & 3 & 0 & 0 & 1 & 2 & 0 & 3 \\
\hline Physalaemus biligonigerus & 1 & 3 & 0 & 0 & 1 & 2 & 0 & 3 \\
\hline Pseudopaludicola falcipes & 1 & 3 & 0 & 0 & 1 & 2 & 0 & 1 \\
\hline \multicolumn{9}{|l|}{ Leptodactylidae } \\
\hline Leptodactylus chaquensis & 1 & 3 & 0 & 0 & 1 & 2 & 1 & 3 \\
\hline Leptodactylus fuscus & 1 & 3 & 0 & 0 & 1 & 2 & 0 & 3 \\
\hline Leptodactylus gracilis & 1 & 3 & 0 & 0 & 1 & 2 & 0 & 3 \\
\hline Leptodactylus latinasus & 1 & 3 & 0 & 0 & 1 & 2 & 0 & 3 \\
\hline Leptodactylus mystacinus & 1 & 3 & 0 & 0 & 1 & 2 & 0 & 3 \\
\hline Leptodactylus ocellatus & 1 & 3 & 0 & 0 & 1 & 2 & 1 & 3 \\
\hline \multicolumn{9}{|l|}{ Microhylidae } \\
\hline Elachistocleis bicolor & 0 & 1 & 0 & 0 & 3 & 2 & 0 & 1 \\
\hline
\end{tabular}

Eye position $=1$, dorsal $/ 0$, lateral; oral position $=1$, terminal $/ 2$, subterminal $/ 3$, ventral; spiracle position $=1$, lateral $/ 2$, ventral $/$ 3 , terminal; dorsal and ventral fin height $=1$, higher than the tail muscle at the body-tail juncture/ 2 , lower than the tail muscle at the body-tail juncture; body height/width ratio = 1, equal to or greater than one/ 2, less than one; clutch deposition $=1$, directly in water/ 2 , arboreal/ 3 , with foam nests; schooling behaviour $=1$, present/ 0 , absent.

\section{Spatial structure}

Limitations on dispersal and similarity in environmental conditions between nearby sites generally result in a pattern of distance decay in similarity between communities (Urban 2004). It has been well demonstrated that this spatial autocorrelation in community similarity violates the statistical assumption of independence and may increase the probability of type I error (Legendre et al. 2004). Therefore, we assessed the spatial autocorrelation in species composition using the Mantel test. Additionally, we assessed the spatial autocorrelation after accounting for similarities in environmental factors using the partial Mantel test. The matrices of geographical distance and environmental dissimilarity were obtained using the Euclidean distance, and that of species abundances using the Chord distance (Orlóci 1967). The Chord distance between sampling units takes into account differences in total abundances and also standardizes variables, securing a monotonic relationship between descriptors (Legendre \& Legendre 1998). A detailed description of the use of the Mantel test for spatial analysis is available in Dale et al. (2002).

\section{Richness and guild composition models}

We regressed tadpole richness with abundance of individuals $(\log )$, and employed the regression residuals in the following analysis $\left(R^{2}=0.07 ; F_{2,35}=2.76 ; P=0.10\right)$. A matrix of guild composition was compiled, summing the abundances of species belonging to each guild type. We obtained a distance matrix of guilds based on Chord distance (Orlóci 1967), and carried out a non-metric multidimensional scaling (NMDS) to ordinate guild composition in ponds in a single dimension (Legendre \& Legendre 1998). We tested the effects of all environmental variables measured on tadpole richness and the scores of ponds on the NMDS axis obtained from the guild data, using multiple linear regressions, with backward stepwise removal of non-significant predictors (Sokal \& Rohlf 1994).

\section{RESULTS}

Of the 38 ponds with water in the spring sampling, only 21 still contained water in the following summer sampling event. The permanence degree of the ponds ranged from 0 , observed in 17 ponds that fully dried, to 1.0 , observed in a single pond. Fish were found in 13 ponds, but only one pond contained predatory fish (Astyanax sp., Characidae). Macroinvertabrate predators were present in all the ponds. A total of 10852 individuals of 21 species of tadpoles were collected in the two sampling events. The tadpoles belonged to 


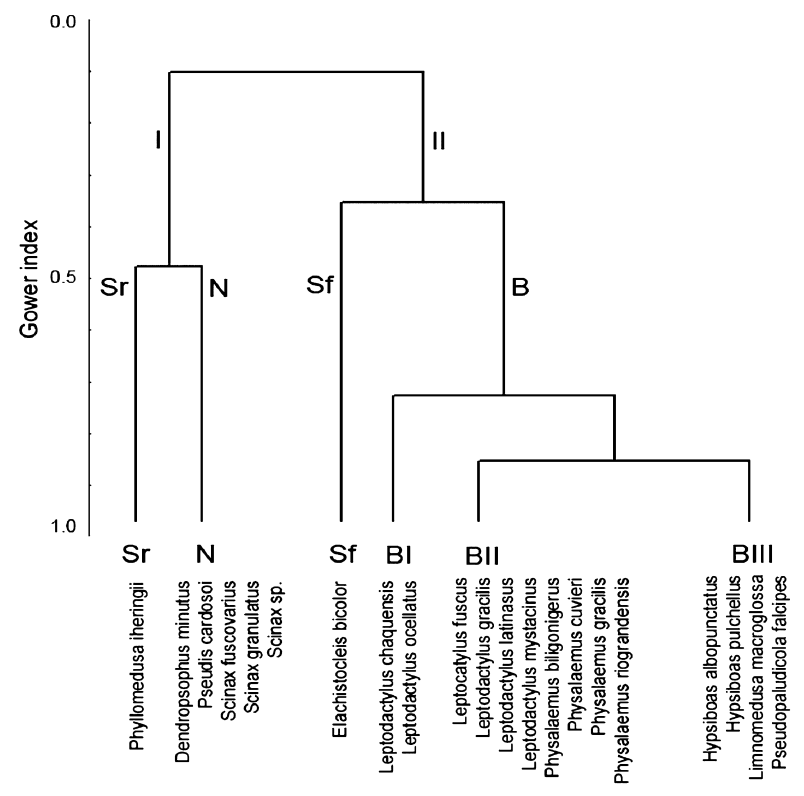

Fig. 1. Classification of 21 tadpole species into six ecomorphological guilds on the basis of the variables listed in Table 1. Species were classified through complete linkage, using the Gower similarity index. Tadpoles were first segregated into two large groups related with body hydrodynamic. Group I included only species with the body height-width ratio close to or greater than one; group II includes tadpoles with the body height-width ratio less than one. With about $60 \%$ of similarity, we had four groups: $\mathrm{Sr}$, suspension-rasper; $\mathrm{N}$, nektonic; Sf, suspension-filter; B, benthic. The final classification showed six groups, and benthic species were further divided.

families Cycloramphidae (one), Hylidae (eight), Leiuperidae (five), Leptodactylidae (six) and Microhylidae (one) (see Table 1). Pond richness ranged from one to eight species (mean $=4.3$, standard deviation $(S D)=2.4)$. Pond abundances ranged from 1 to 1921 individuals (mean $=285.6, \mathrm{SD}=471.4$ ). Communities of nearby ponds were not more similar than those from more-distant ponds $(r=0.06, P=0.16)$, even after removing the effects of spatially structured environmental descriptors $(r=0.06, P=0.14)$.

\section{Guild classification}

Tadpoles were first segregated into two large groups according to body hydrodynamic morphology (Fig. 1). Group I included only species of Hylidae, and was characterized by tadpoles with the body height-width ratio close to or greater than one. This group includes the nektonic and suspension-rasper guilds. Group II includes tadpoles of five families. The group included species characterized by a body height-width ratio less than one. With about $60 \%$ of similarity, we had four groups, all them included in the guild classification of
Altig and Johnston (1989). The final classification revealed six guilds: suspension-rasper $(\mathrm{Sr})$, nektonic $(\mathrm{N})$, suspension-filter $(\mathrm{Sf})$, benthic with foam nests with (BI) and without (BII) schooling behaviour and benthic without foam nests (BIII) (Fig. 1). We attempted to name the guilds according to previous classifications, and therefore we maintained the terms suspension-rasper and suspension-filter, although feeding characteristics were not included in the present study.

\section{Richness and guild composition}

The ordination of ponds based on guild composition on a single NMDS axis showed a stress of 0.28 . For each pond, we obtained the relative abundance of guilds and plotted them against the order in which the ponds were scored on the single NMDS axis (Fig. 2). Guild abundances were clearly separated along the NMDS axis.

The multiple regression analysis revealed a positive relationship between tadpole richness, and invertebrate predator abundance and mean summer depth $\left(R^{2}=0.40, F_{2,35}=11.95, P<0.001\right)$. The guild composition (NMDS scores) was affected negatively by permanence and mean summer depth $\left(R^{2}=0.34\right.$, $\left.F_{2,35}=9.04, P<0.001\right)$.

\section{DISCUSSION}

\section{Guild classification}

The guild delineation was mostly congruent with previous proposals (Altig \& Johnston 1989; McDiarmid \& Altig 1999). Species were initially segregated by hydrodynamic traits such as body height/width ratio and compressed/depressed forms. Further divisions resulted in the Altig and Johnston (1989) guild classification. The benthic group defined was further separated into three guilds.

The benthic species were initially separated into two groups, based mostly on the presence of foam nests (BI-BII and BIII, Fig. 1). Foam nests protect embryos against drought and thus allow species to exploit unpredictable ephemeral habitats (Heyer 1969; Vasconcelos \& Rossa-Feres 2005). This foam-building group (BI-BII) was composed by species of Leptodactylus (Leptodactylidae) and Physalaemus (Leiuperidae), and was further separated into guilds with (BI) or without (BII) schooling behaviour. Guild BI was composed of species of the Leptodactylus ocellatus group. Considering that guilds are composed of species that use resources in a similar way (Root 1964), it would be expected that the first group, which 

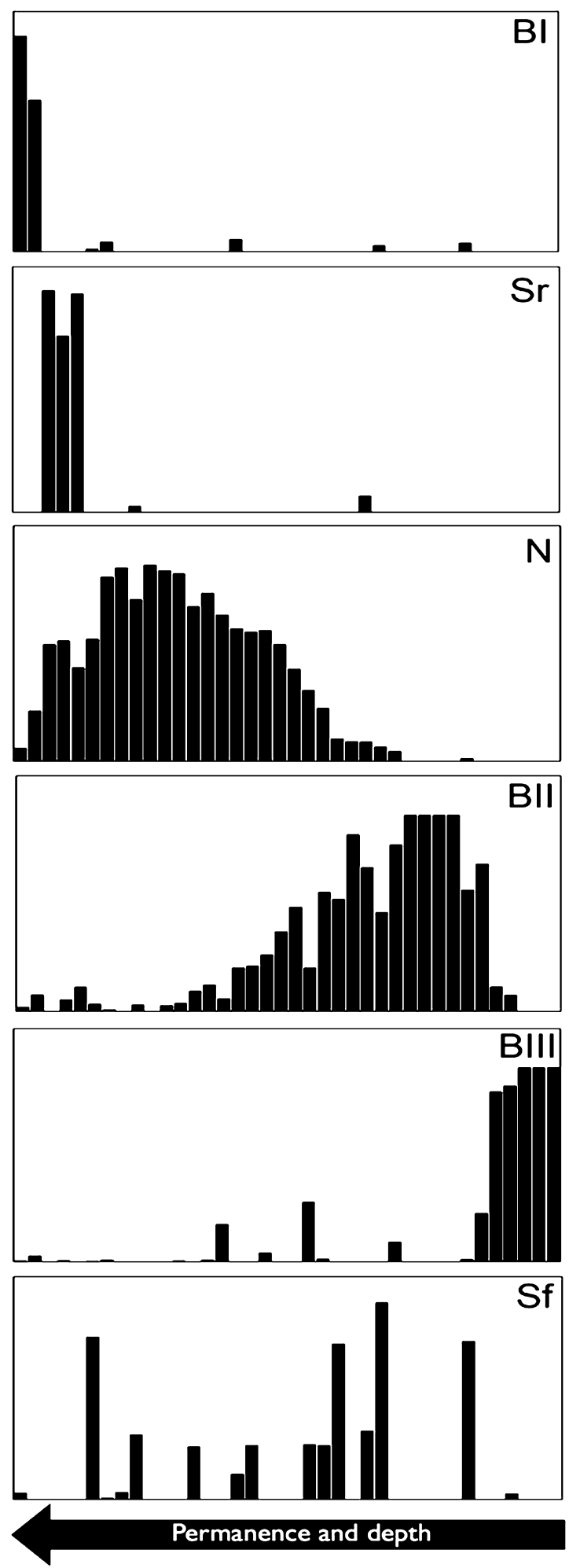

Fig. 2. Relative abundance of six guilds in 38 ponds, ordered by the NMDS vector of composition (stress $=0.28$ ). Abundances were standardized by the marginal totals within respective guilds and ponds. Arrow indicates the direction of gradient of permanence and depth tested in the multiple regression. BI-BIII, benthic of types I-III; N, nektonic; Sf, suspension-filter; $\mathrm{Sr}$, suspension-rasper. forms dense schools and occupies larger ponds than other Leptodactylus species, would belong to a different category.

\section{Richness and guilds across environmental gradients}

The theoretical model proposed by Wellborn et al. (1996) for freshwater pond communities suggests that fish presence and drought are the main factors governing the occurrence of tadpoles across the permanencepredation gradient. Few of the ponds sampled in this study contained fish, and only one housed a predatory fish species. Therefore, our study sites were positioned along one end through intermediate positions of the gradient. Accordingly, the expected species traits should mostly result from constraints imposed by drought and invertebrate predators. Although restricted to part of the gradient, our results supported the permanence-predation expectations, because the abundance of predators positively affected tadpole richness, and the degree of permanence predicted guild composition.

Invertebrate predators, which showed a positive effect on tadpole richness, can affect communities in a variety of ways, such as: (i) direct predation pressure, reducing survival (Kats et al. 1988); (ii) elimination of superior competitors, which makes space for weaker ones (Alford 1999); and (iii) differential predation regarding prey size (Wilbur 1997). Predation mediating tadpole coexistence could explain the positive effect found, and was also suggested as an important factor in studies in which the predators were predominantly macroinvertebrates (e.g. Richter-Boix \& Llorente 2007; Both et al. 2009). We note, however, that it is not possible to establish a cause-and-effect relationship because our study was not able to eliminate the plausible hypothesis of a bottom-up effect, in which ponds with more tadpole diversity would attract more invertebrate predators.

The relationship between species richness and environmental gradients has been widely assessed for many taxa, whereas studies of guild composition across gradients still remain scarce for most groups. One of the most complete studies about guild structure across gradients was carried out with North American mammals, where species-richness peaks of each guild were associated with a particular set of environmental conditions (Badgley \& Fox 2001). We believe that the demonstration of the effect of the permanence gradient for structuring tadpole guilds is the major contribution of this study. We found that the type I benthic and suspension-rasper species occurred nearly exclusively in deep, permanent ponds, whereas nektonic species tended to occur in permanent and semi-permanent ponds. Type II 
benthic species tended to occur in semi-permanent and temporary ponds, whereas type III benthic species were found mostly in temporary ponds. Suspension-filter tadpoles were not associated with specific parts of the permanence gradient. Snodgrass et al. (2000) found that species associated with small ponds were not a subset of the species pool of larger ponds. The limitation of species with foam nests (guilds BI and BII) to temporary ponds, and of some species of Hylidae, those here classified as type IV benthics, to permanent ponds has also been reported in other studies (e.g. Kwet 2001; Santos et al. 2007; Both et al. 2009).

Depth was an important predictor for both richness and composition. Deep ponds that retain water during dry periods permit the development of species with different breeding periods. The position in the water column was not used for guild delineation, but, following Altig and Johnston (1989), the different guilds are intrinsically related to the position in the water column and/or swimming ability. For instance, species with very high tail fins and a compressed body would be more restricted to shallow ponds than would species with low tail fins and a depressed body. Other studies also found species or species groups associated with depth gradients. Eterovick and Fernandes (2001) studied tadpole communities in streams, and found that position in the water column and water depth were the most important variables to differentiate the species' microhabitat use. Kushlan (1976) reported that water depth structures fish communities in marshes, predicting the richness increase, and modulating the dominance of species and the number of large carnivorous species present.

One last point for consideration is the lack of spatial autocorrelation of richness and guild composition, which implies that pond factors more than spatial factors determine community structure at the scale studied. Our results indicate that water depth and the abundance of invertebrate predators were the main factors affecting richness, while water depth and permanence predicted the guild composition replacement. Even very small, shallow and ephemeral ponds are important, given that some species groups are exclusive to such habitats, and a guild replacement occurs across the gradients of permanence and depth. Therefore, rich ponds would not contain species from all guilds.

\section{ACKNOWLEDGEMENTS}

We thank B. Madalozzo, I.L. Kaefer, G. Soares, T. Dalcin and A.P. Santos Jr. for help in field and/or laboratory activities. We also thank the rural owners who permitted access to ponds. We are grateful for the valuable suggestions of A. Kindel, D.C. Rossa-Feres and T. Grant on an earlier version of the manuscript, and for suggestions of the reviewers and the editor in this version. IBAMA granted a permit for this study (Process 11689-1). CB was supported by a CAPES fellowship. ASM received a research fellowship (302482/2008-3) and grant (476304/2007-5) from the Conselho Nacional de Desenvolvimento Científico e Tecnológico $(\mathrm{CNPq})$. $\mathrm{SH}$ received a research fellowship (304036/2007-2) from CNPq.

\section{REFERENCES}

Alford R. A. (1999) Ecology: resource use, competition and predation. In: Tadpoles: The Biology of Anuran Larvae (eds R. McDiarmid \& R. Altig) pp. 240-78. The University of Chicago Press, Chicago/London.

Altig R. \& Johnston G. F. (1989) Guilds of anuran larvae: relationships among developmental modes, morphologies, and habitats. Herpetological Monographs 3, 81-109.

Badgley C. \& Fox D. L. (2001) Ecological biogeography of North American mammals: species density and ecological structure in relation to environmental gradients. $\mathcal{F}$. Biogeogr. 27, 1437-67.

Bocard D., Legendre P. \& Drapeau P. (1992) Partialling out the spatial component of ecological variation. Ecology 73, 104555.

Both C., Kaefer I. L., Santos T. G. \& Cechin S. Z. (2008) An austral anuran assemblage in the Neotropics: seasonal ocurrence correlated with photoperiod. F. Nat. Hist. 42, 205-22.

Both C., Solé M., Santos T. G. \& Cechin S. Z. (2009) The role of spatial and temporal descriptors for neotropical tadpole communities in southern Brazil. Hydrobiologia 624, 125-38.

Canavero A., Arim M., Naya D. E., Camargo A., Rosa I. \& Maneyro R. (2008) Calling activity patterns in an anuran assemblage: the role of seasonal trends and weather determinants. North-West. F. Zool. 4, 29-41.

Chase J. M. \& Leibold M. A. (2003) Ecological Niches: Linking Classical and Contemporary Approaches. The University of Chicago Press, Chigago/London.

Dale M., Dixon P., Fortin M. J., Legendre P., Myers D. \& Rosenberg M. (2002) Conceptual and mathematical relationships among methods for spatial analysis. Ecography 25, 558-77.

Devoto M., Medan D., Roig-Alsina A. \& Montaldo N. H. (2009) Patterns of species turnover in plant-pollinator communities along a precipitation gradient in Patagonia. Austral Ecol. 34, 848-57.

Eason G. W. J. \& Fauth J. E. (2001) Ecological correlates of anuran species richness in temporary pools: a field study in South Carolina, USA. Isr. F. Zool. 47, 347-65.

Ernst R. \& Rödel M. (2008) Patterns of community composition in two tropical tree frog assemblages: separating spatial structure and environmental effects in disturbed and undisturbed forests. F. Trop. Ecol. 24, 111-20.

Eterovick P. C. \& Fernandes G. W. (2001) Tadpole distribution within montane meadow streams at the Serra do Cipó, southeastern Brazil: ecological or phylogenetic constraints? 7. Trop. Ecol. 17, 683-93.

Faivovich J. (2002) A cladistic analysis of Scinax (Anura: Hylidae). Cladistics 18, 367-93. 
Gotelli N. J. \& McCabe D. J. (2002) Species co-ocurrence: a meta-analysis of J. M. Diamond's assembly rules model. Ecology 83, 2091-6.

Hardy O. J. \& Senterre B. (2007) Characterizing the phylogenetic structure of communities by an additive partitioning of phylogenetic diversity. F. Ecol. 95, 493-506.

Hero J., Magnusson W. E., Rocha C. F. D. \& Caterall C. P. (2001) Antipredator defenses influence de distribution of amphibian prey species in the Central Amazon Rain Forest. Biotropica 33, 131-41.

Heyer W. R. (1969) The adaptative ecology of the species groups of the genus Leptodactylus (Amphibia, Leptodactylidae). Evolution 23, 421-8.

Hubbell S. P. (2001) The Unified Neutral Theory of Biodiversity and Biogeography. Princeton University Press, Princeton.

Kats L. B., Petranka J. W. \& Sih A. (1988) Antipredator defenses and the persistence of amphibian larvae with fishes. Ecology 69, 1865-70.

Krebs C. J. (2009) Ecology: The Experimental Analysis of Distribution and Abundance. Benjamin Cummings, San Francisco.

Kushlan J. A. (1976) Environmental stability and fish community diversity. Ecology 57, 821-5.

Kwet A. (2001) Frösche in brasilianischen Araukarienwald Anurengemainschaft des Araukarienwaldes von Rio Grande do Sul: Diversität, Reproduktion und Ressourcenaufteilung. Natur und Tier-Verlag, Münster.

Lawton J. H. (1999) Are there general laws in ecology? Oikos 84, 177-92.

Legendre P. \& Fortin M. J. (1989) Spatial pattern and ecological analysis. Vegetatio 80, 107-38.

Legendre P. \& Legendre L. (1998) Numerical Ecology. Elsevier Scientific Publishing Company, Amsterdam.

Legendre P., Dale M. R. T., Fortin M., Casgrain P. \& Gurevitch J. (2004) Effects of spatial structures on the results of field experiments. Ecology 8512, 3202-14.

McDiarmid R. W. \& Altig R. (1999) Tadpoles: The Biology of Anuran Larvae. The University of Chicago Press, Chicago/ London.

Maluf J. R. T. (2000) Nova classificação climática do Estado do Rio Grande do Sul. Rev. Bras. Agrometeorol. 8, 141-50.

Orlóci L. (1967) An agglomerative method for classification of plant communities. F. Ecol. 55, 193-205.

Peltzer P. M. \& Lajmanovich R. C. (2004) Anuran tadpole assemblages in riparian areas of the Middle Paraná River, Argentina. Biodivers. Conserv. 13, 1833-42.

Pillar V. D. (2006) MULTIV: multivariate exploratory analysis, randomization testing and bootstrap resampling. Available from the URL: http://ecoqua.ecologia.ufrgs.br
Richter-Boix A. \& Llorente G. A. (2007) A comparative study of predator-induced phenotype in tadpoles across a pond permanence gradient. Hydrobiologia 583, 43-56.

Root R. B. (1964) Ecological interactions of the chestnut-backed chickadee following a range extension. Condor 66, 229-38.

Santos T. G., Rossa-Feres D. C. \& Casatti L. (2007) Diversidade e distribuição espaço temporal de anuros em região com pronunciada estação seca no sudeste do Brasil. Iheringia Série Zool. 97, 37-49.

Simberloff D. (2004) Community ecology: is it time to move on? Am. Nat. 163, 787-99.

Skelly D. K. (1996) Pond drying, predators, and the distribution of Pseudacris tadpoles. Copeia 1996, 599-605.

Snodgrass J. W., Komoroski M. J., Bryan A. L. \& Burger J. (2000) Relationships among isolated wetland size, hydroperiod, and amphibian species richness: implications for wetland regulations. Conserv. Biol. 14, 414-9.

Sokal R. R. \& Rohlf F. J. (1994) Biometry. W. H. Freeman \& Company, New York.

StatSoft I. (2001) STATISTICA (data analysis software system). Available from URL: http://www.statsoft.com

Stenert C. \& Maltchik L. (2007) Influence of area, altitude and hydroperiod on macroinvertebrate communities in southern Brazil wetlands. Mar. Freshwater Res. 58, 993-1001.

Tarr T. L., Baber M. J. \& Babbit K. J. (2005) Macroinvertebrate community structure across a wetland hydroperiod gradient in southern New Hampshire, USA. Wetlands Ecol. Manage. 13, 321-34.

Urban M. C. (2004) Disturbance heterogeneity determines freshwater metacommunity structure. Ecology 85, 2971-8.

Vanschoenwinkel B., Hulsmans A., De Roeck E., De Vries C., Seaman M. \& Brendonck L. (2009) Community structure in temporary freshwater pools: disentangling the effects of habitat size and hydroregime. Freshwater Biol. 54, 1487500 .

Vasconcelos T. S. \& Rossa-Feres D. C. (2005) Diversidade, distribuição espacial e temporal de anfíbios anuros (Amphibia: Anura) na região noroeste do Estado de São Paulo, Brasil. Biota Neotrop. 5, 1-14.

Wellborn G. A., Skelly D. K. \& Werner E. E. (1996) Mechanisms creating community structure across a freshwater habitat gradient. Annu. Rev. Ecol. Syst. 27, 337-63.

Werner E. E., Skelly D. K., Relyea R. A. \& Yurewicz K. L. (2007) Amphibian species richness across environmental gradients. Oikos 116, 1697-712.

Wilbur H. M. (1997) Experimental ecology of food webs: complex systems in temporary pond communities. Ecology 78, 2279-302. 